\title{
A rare congenital anomaly of mediastinal vascular structures; isolated retroaortic left brachiocephalic vein
}

\section{Mediastinal vasküler yapıların nadir bir konjenital anomalisi; izole retroaortik sol brakiosefalik ven}

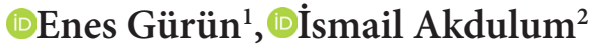 \\ ${ }^{1}$ İskilip Atıf Hoca State Hospital, Çorum, Turkey \\ ${ }^{2}$ Department of Radiology, Gazi University, Ankara, Turkey
}

Cite this article as/Bu makaleye atıf için: Gürün E, Akdulum İ. A rare congenital anomaly of mediastinal vascular structures; isolated retroaortic left brachiocephalic vein. J Health Sci Med 2020; 3(4): 499-502.

\begin{abstract}
Retroaortic left brachiocephalic vein (RALBV) is a rare condition and frequently accompanies congenital heart diseases. Isolated retroaortic left brachiocephalic vein anomaly is extremely rare. We emphasized the importance of the embryology and anatomy of the isolated RALBV anomaly and revealed the need to be assessed before the intervention. A 55-year-old man who underwent lobectomy due to lung adenocarcinoma. The patient had no known cardiac anomaly or heart disease. There was an oval-shaped structure reported as enlarged lymph node in the preaortic area on previous non-contrast CT. In the contrast-enhanced thorax computed tomography, it was seen that the structure previously described as lymph node was the left brachiocephalic vein, which showed a retroaortic course and was opacified with contrast material. In conclusion, isolated RALBV is an extremely rare anomaly. Due to the increasing numbers of cross-sectional exams, this phenomenon should be recognized and reported. Physcians should be notified before the radiological interventional procedures or thoracic surgery. Additionally, it is necessary to be careful since the treatment and follow-up of malignant diseases might be affected by misinterpretations.
\end{abstract}

Keywords: Computed tomography, isolated retroaortic left brachiocephalic vein, lung adenocarcinoma

\begin{abstract}
ÖZ
Retroaortik sol brakiosefalik ven (RALBV) nadir bir durumdur ve sıklıkla doğumsal kalp hastalıklarına eşlik eder. İzole RALBV anomalisinin embriyoloji ve anatomisinin önemini bilinmeli ve müdahale öncesinde akılda tutulması gerekmektedir.Akciğer adenokarsinomu nedeniyle lobektomi yapılan 55 yaşında erkek hasta. Hastanın bilinen kalp anomalisi veya kalp hastalığı yoktu. Daha önceki kontrastsız BT'de preaortik alanda büyümüş lenf nodu olarak bildirilen oval şekilli bir yapı vardı. Hastaya yapılan kontrastlı toraks bilgisayarlı tomografisinde daha önce lenf nodu olarak tanımlanan yapının, retroaortik seyir gösteren ve kontrast madde ile opasifiye olan sol brakiyosefalik ven olduğu görüldü.Sonuç olarak izole RALBV oldukça nadir görülen bir anomalidir. Kesitsel incelemelerin artması nedeniyle bu anomali bilinmeli ve rapor edilmelidir. Radyolojik girişimsel prosedürler ve göğüs ameliyatları öncesinde dikkatli olunmalıdır. Ayrıca yanlış yorumlar malign hastalıkların tedavisini ve takibini etkileyebileceğinden dikkatli olmak gerekmektedir.
\end{abstract}

Anahtar Kelimeler: Bilgisayarlı tomografi, izole retroaortik sol brakiosefalik ven, akciğer adenokanseri

\section{INTRODUCTION}

The left retroaortic brachiocephalic vein is formed by the union of the subclavian vein and the internal jugular vein. This structure then passes anterior to the supraaortic branches of the aortic arch and joins with the right brachiocephalic vein to form the superior vena cava. Retroaortic left brachiocephalic vein is a rare condition and frequently accompanies congenital heart diseases. Isolated retroaortic left brachiocephalic vein anomaly is extremely rare (1).

\section{CASE REPORT}

A 55-year-old male patient, who had a history of lobectomy due to lung adenocarcinoma, was admitted to the radiology department for routine follow-up. The patient had no known cardiac anomaly or heart disease. There was an oval-shaped structure that was reported as an enlarged lymph node in the preaortic area on noncontrast CT, previously performed in an external center (Figure 1). Contrast-enhanced thorax and abdomen computed tomography was performed on the patient. 


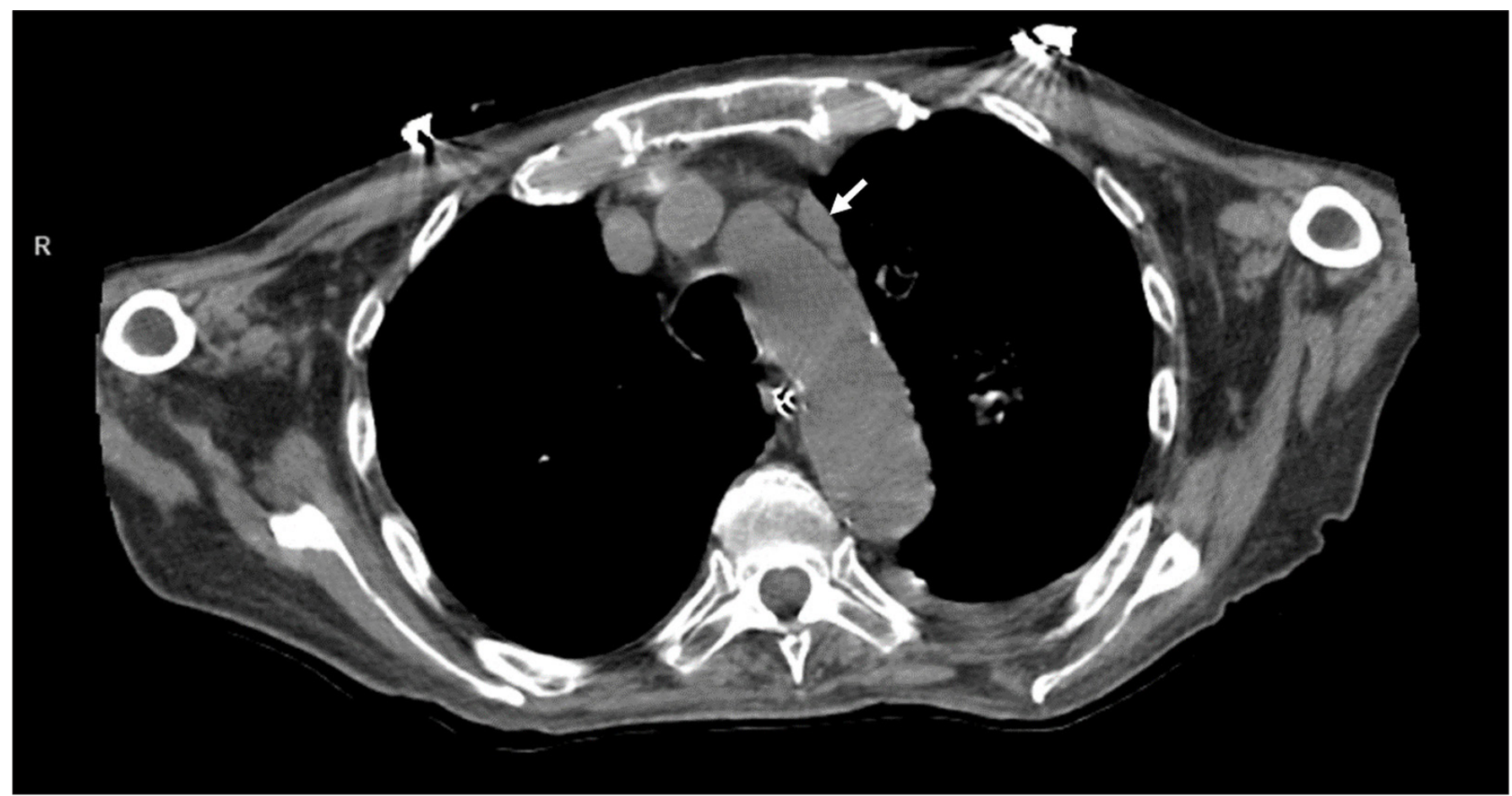

Figure 1. RALBV (arrow) observed anterior to the anterior left of the aortic arch on an axial non-contrast CT scan was misinterpreted as mediastinal LAP.

CT parameters were as follows: $2 \times 192 \times 0.6 \mathrm{~mm}$ slice collimation using $\mathrm{z}$-axis flying focal spot technique; 0.25 $\mathrm{s}$ gantry rotation time; temporal resolution of $66 \mathrm{~ms}$ and an isotropic resolution of $0.3 \mathrm{~mm}$. Automated tube voltage were used according to the patient's size. Images were acquired from the thoracic inlet to the pelvis. 100 $\mathrm{ml}$ iodinated contrast medium (iohexol, iodine content $350 \mathrm{mg} / \mathrm{mL}$; Omnipaque TM, GE Healthcare) was intravenously administered via the cubital vein. After contrast medium injection, $30 \mathrm{cc}$ saline solution injected. The flow rate of contrast and saline was $2 \mathrm{~mL} / \mathrm{s}$.

During the routine follow-up of the patient, we performed the contrast-enhanced CT examination.

The left brachiocephalic vein with a retroaortic course and opacification with contrast agent has been shown to be the structure previously defined as oval shaped. (Figure 2-3).

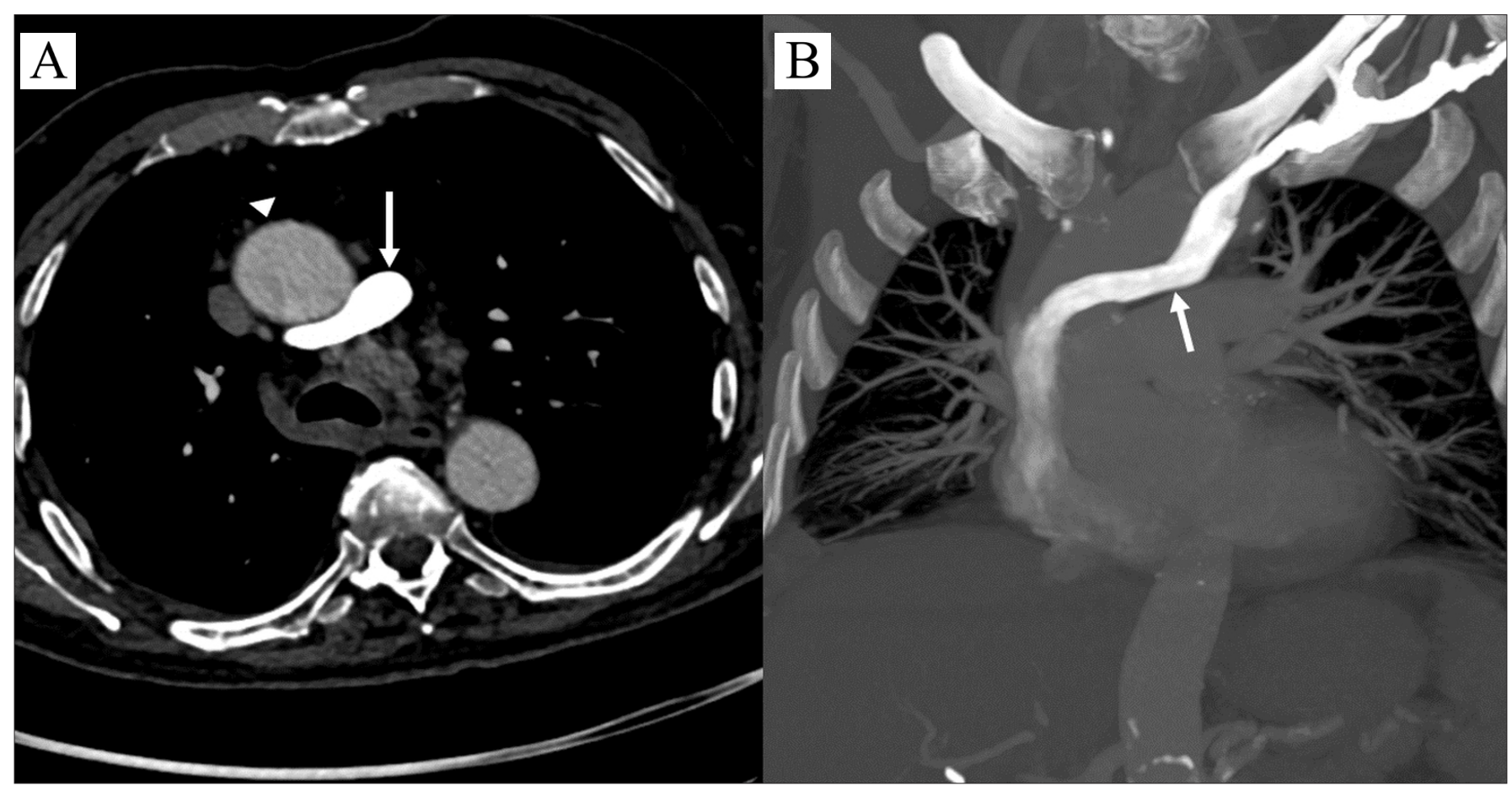

Figure 2. Post-contrast axial CT (a) and coronal MIP (b) images show contrast agent administration from the left arm. It shows that the left brachiocephalic vein (arrow) passes from the posterior of the ascending aorta (arrowhead) to the right half of the mediastinum. 


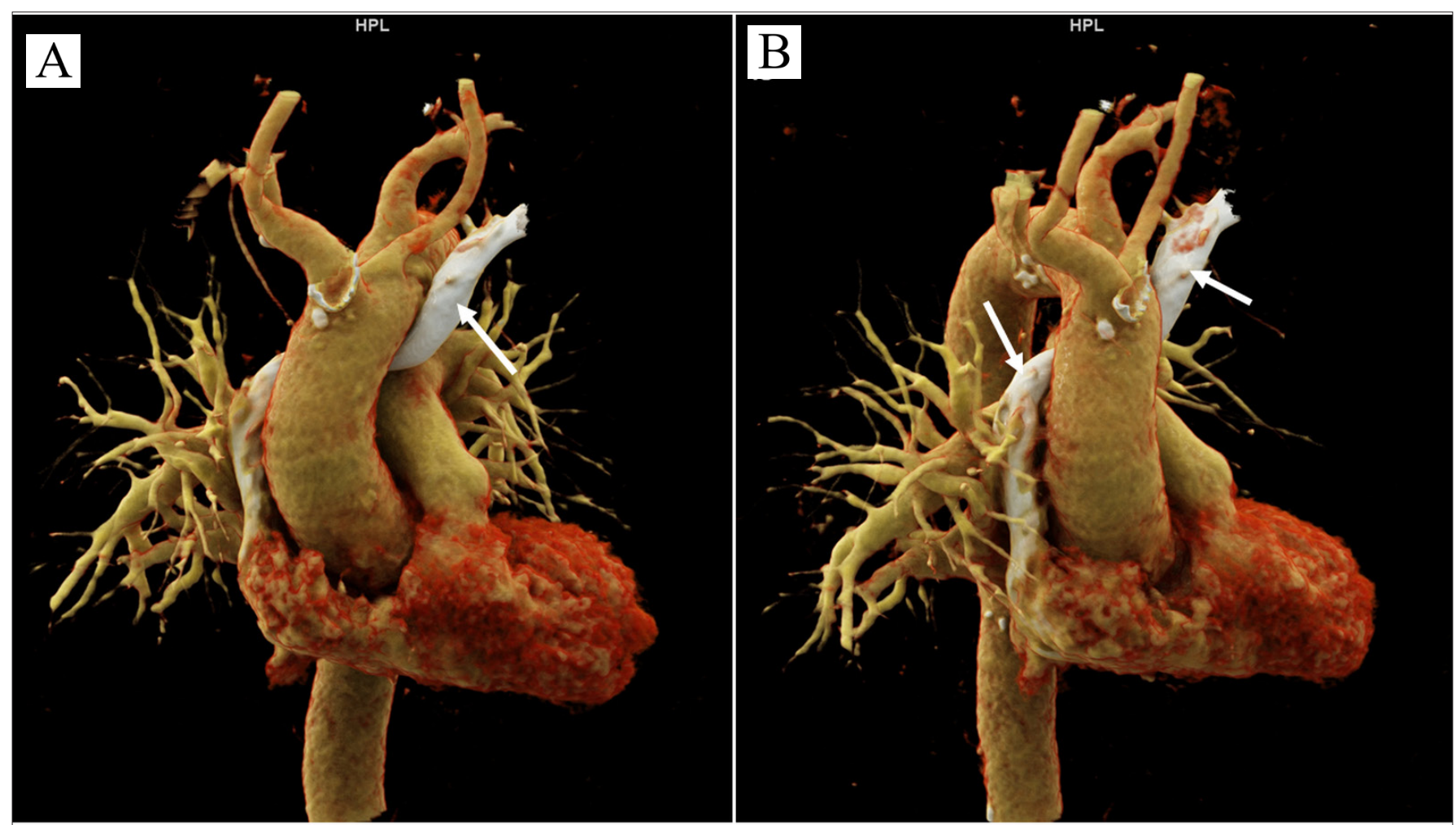

Figure 3. The reformatted volume rendering technique (VRT) images show a retroaortic left brachiocephalic vein (arrow)

\section{DISCUSSION}

Retroaortic left brachiocephalic vein is an extremely rare vascular anomaly, often accompanied by congenital heart disease. It frequently accompanies with other congenital heart diseases such as tetralogy of fallot and right aortic arch, pulmonary venous return anomaly, aortic coarctation, right atrial isomerism, atrial septal defect and ventricular septal defect (2-4). In a retrospective study conducted on 1812 cases by Chen et al. (4) covering an 8-year period, RALBV abnormalities were found in 27 cases. They found the incidence to be approximately $1.7 \%$ in patients with congenital heart disease. In other studies, in the literature, this rate was found to be approximately 0.55-0.57 (5,6).

Isolated RALBV anomaly that does not accompany with any other congenital cardiac anomaly is extremely rare. Nagashima et al. (7) found only one isolated RALBV anomaly without congenital heart anomaly in a study of 4805 cases. In other studies, in the literature, isolated RALBV anomaly not accompanying congenital heart disease was found to be approximately $0.02 \%$ (8).

The mechanism of RALBV formation is not yet clear. During normal embryological development, the rightleft anterior and posterior cardinal veins merge to form the right and left common cardinal veins. The anterior cardinal veins extend superiorly on both sides and join with the internal jugular vein and subclavian vein. In the following period, most of the left anterior cardinal vein disappears and merges with transverse anastomotic channels. It will then merge with the right common cardinal vein to form the superior vena cava. The left common cardinal vein forms the coronary sinus, and the remaining part of the left anterior cardinal vein forms the oblique vein of the marshal $(4,9)$. It is thought that the absence of fusion in transverse anastomotic ducts and formation of alternative anastomoses play a role in the formation of RALBV anomaly $(4,10)$.

Detection of isolated RALBV anomaly is clinically very important. With the widespread use of cross-sectional examinations, it is necessary to be careful since isolated RALBV anomaly can be seen even in cases without any congenital cardiac anomaly. Additionally, since it frequently accompanies with $\mathrm{CHD}$, the presence of other cardiac anomalies should be investigated in detail in cases with RALBV anomaly. Isolated RALBV can be reported as an enlarged lymph node in non-contrast CT examinations (11). As in our case, this situation is critical in guiding the follow-up and treatment of malignant diseases such as lung adenocarcinoma. In addition, if this variation is not known beforehand, it may cause technical difficulties during cardiothoracic surgeries, leftsided venous interventional procedures such as central venous catheterization, and cardiological interventional procedures such as pacemaker placement. 


\section{CONCLUSIONS}

Isolated RALBV is an extremely rare anomaly. Due to the increasing numbers of cross-sectional exams, this phenomenon should be recognized and reported. One should be alert before radiological interventional procedures and thoracic surgeries. Additionally, it is necessary to be careful since the treatment and follow-up of malignant diseases might be affected by misinterpretations.

\section{ETHICAL DECLARATIONS}

Informed Consent: Written informed consent was obtained from all participants who participated in this study.

Status of Peer-review: Externally peer-reviewed.

Conflict of Interest Statement: The authors have no conflicts of interest to declare.

Financial Disclosure: The authors declared that this study has received no financial support.

Author Contributions: All of the authors declare that they have all participated in the design, execution, and analysis of the paper, and that they have approved the final version.

\section{REFERENCES}

1. Srinivasan S, Kannivelu A, Ali SZ, See PL. Isolated retroaortic left innominate vein in an adult without cardiac or aortic anomalies. Indian J Radiol Imaging. 2013; 23: 308-9.

2. Kulkarni S, Jain S, Kasar P, Garekar S, Joshi S. Retroaortic left innominate vein-Incidence, association with congenital heart defects, embryology, and clinical significance. Ann Pediatr Cardiol 2008; 1: 139-41.

3. Bartoli JM, Chagnaud C, Moulin G, Di Stefano-Louineau D, Bory M, Kasbarian M. Pseudocoarctation of the aorta associated with retro-aortic left brachiocephalic vein: a case report. Surg Radiol Anat 1990; 12: 307-9.

4. Chen SJ, Liu KL, Chen HY, et al. Anomalous brachiocephalic vein: CT, embryology, and clinical implications. AJR Am J Roentgenol 2005; 184: 1235-40.

5. Choi JY, Jung MJ, Kim YH, Noh CI, Yun YS. Anomalous subaortic position of the brachiocephalic vein (innominate vein): an echocardiographic study. Br Heart J 1990; 64: 385-7.

6. Curtil A, Tronc F, Champsaur G, et al. The left retro-aortic brachiocephalic vein: morphologic data and diagnostic ultrasound in 27 cases. Surg Radiol Anat 1999; 21: 251-4.

7. Nagashima M, Shikata F, Okamura T, et al. Anomalous subaortic left brachiocephalic vein in surgical cases and literature review. Clin Anat 2010; 23: 950-5.

8. Takada Y, Narimatsu A, Kohno A, et al. Anomalous left brachiocephalic vein: CT findings. J Comput Assist Tomogr 1992; 16: 893-6.

9. Ko SF, Huang CC, $\mathrm{Ng} \mathrm{SH}$, et al. Imaging of the brachiocephalic vein. AJR Am J Roentgenol 2008; 191: 897-907.
10. Kim SH, Chung JW, Im JG, Choi YW, Choe YH, Han MC. Subaortic left innominate vein: radiologic findings and consideration of embryogenesis. J Thorac Imaging 1999; 14: 142-6.

11. Chern MS, Ko JS, Tsai A, Wu MH, Teng MM, Chang CY. Aberrant left brachiocephalic vein: CT imaging findings and embryologic correlation. Eur Radiol 1999; 9: 1835-9. 